\title{
Assessment of material use in relation to climate in historical buildings
}

\author{
Başak İpekoğlu*, Hasan Böke, Özlem Çizer \\ Department of Architectural Restoration, Faculty of Architecture, İzmir Institute of Technology, 35430 İzmir, Turkey
}

Received 8 September 2005; received in revised form 11 October 2005; accepted 24 October 2005

\begin{abstract}
Climate is among the most significant factors on the environmental performance, life span and/or durability of construction materials in buildings. Although some historical buildings have been abandoned and neglected for a very long period, their existence through centuries can be explained because of their durability to climatic conditions of the area where they are situated. In this study, construction techniques and characteristics of building materials used in some madrasas (historical education buildings) in Western Anatolia (Turkey) were examined in order to evaluate the conditions of the buildings by taking into account climatic conditions of the region. The studied Western Anatolian madrasas, which are in the moderate climatic conditions, were constructed out of rubble stone, brick and mortar in random bond with local workmanship by local builders who continued the older traditions and have survived for more than 300 years without maintenance and repair. On the other hand, most of the madrasa buildings in Central and Eastern Anatolia, which are in the steppe climatic conditions, were differently constructed with cut stone on their exterior surfaces to prevent the main structures of the walls composed of rubble stone and mortar from harsh climatic conditions of these regions. This study indicated that construction techniques and building materials appropriate to the climate might have been intentionally chosen for the survival of historical buildings over the centuries.
\end{abstract}

(C) 2005 Elsevier Ltd. All rights reserved.

Keywords: Historical building materials; Climate; Madrasa; Western Anatolia; Masonry construction

\section{Introduction}

The climate of each locality presents a unique natural environment and is an effective factor on the architectural design and material use. Identifying, understanding and controlling climatic influences at the building site are perhaps the most critical part of the design process $[1,2]$. In this study, construction techniques and characteristics of building materials used in some Ottoman madrasas (madrassa or medrassa) that have existed for more than 300 years, are investigated with a focus on climatic factors.

Madrasas were educational buildings, which organized secondary and higher education in Islamic countries to train the society in religious, cultural and social matters [3-5]. The forerunner madrasas were known to be established in Nishapur [6,7] and Ghazna [8] in the regions of Khorasan and Transoxania (modern Turkmenistan and Uzbekistan)

\footnotetext{
${ }^{*}$ Corresponding author. Fax: + 902327507012.

E-mail address: basakipekoglu@iyte.edu.tr (B. İpekoğlu).
}

during the reign of the Ghaznavids at the end of the 10th and the beginning of the 11th centuries. However, madrasas were improved during the period of the Great Seljuks in the 11th century as organized educational institutions [4]. The first Seljuk madrasas known as 'Nizamiyes' were built in Baghdad, Nishapur, Bosra, Musul, Rey, Isfahan, Merv, Herat, Tus, Balh and Hargird [8]. As none of the 'Nizamiyes' survived until today, no definite information is available as far as their architectural characteristics are concerned. However, the slightly later Great Seljuk madrasas were organized around a large central courtyard, with four monumental iwans (iwan: a vaulted hall, open at one end; used in Islamic architecture), each situated at the center of the sides of the rectangle. Between the iwans there were rows of student rooms [3]. The curriculum of madrasas constituted of Islamic sciences, particularly jurisprudence (fikıh), prophetic traditions (hadith), commentaries of the Quran (tefsir), philosophical theology (kelam) and rational sciences such as philosophy, logic, mathematics, astronomy and medicine. 
Most of the experiments in plan and the different types of madrasa constructions are seen in Early Anatolian Turkish Architecture, during the 12th and the 13th centuries. The Seljuk madrasas in Anatolia present two types of examples as open and closed madrasas. Although the examples of the madrasas with an open courtyard can be seen in all Islamic countries, those that have a central space, covered with a dome are especially developed in Anatolia. Thus, the madrasas of the Anatolian Seljuk period are composed of student rooms and iwans arranged around an open or a closed central space. During this period, the madrasas commonly had two or four vaulted iwans. One of these is at the entrance, the other is across it and the other two are on the sides that open to the central space. The common feature of both types was the huge and monumental portal (a monumental entranceway to a building) placed at the center of the entrance façade and covered with cut stone like the walls (Figs. 1 and 2). In general, the walls and the superstructures were constructed

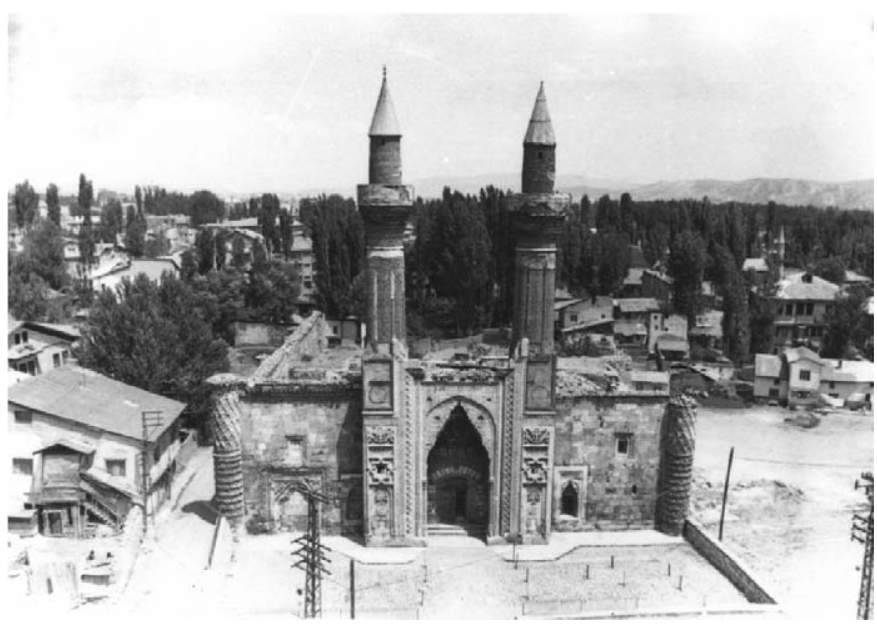

Fig. 1. Portal of Sivas Gök Madrasa, open-court type.

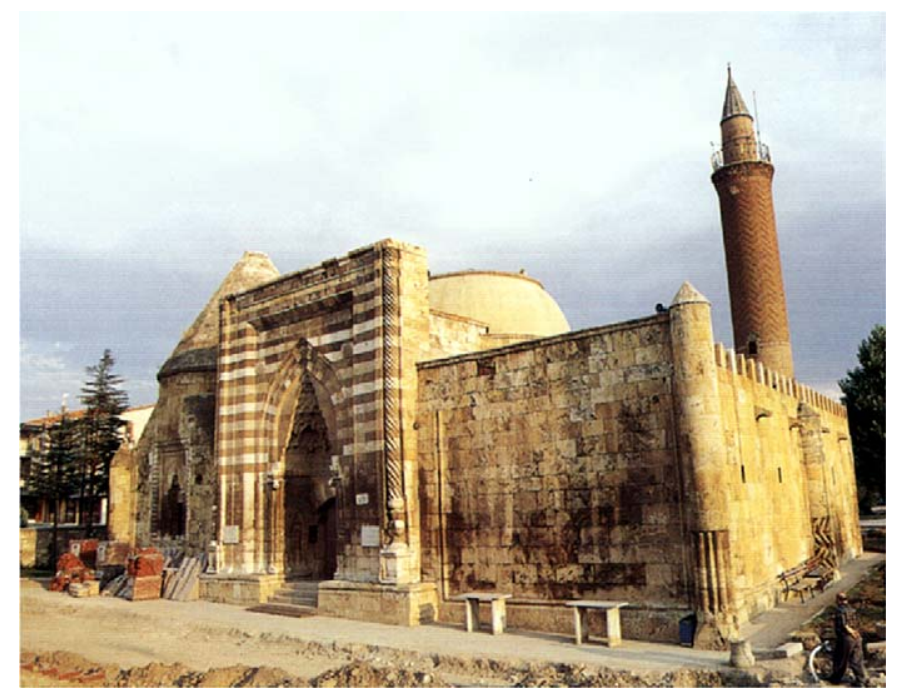

Fig. 2. Portal of Kırșehir, Caca Bey Madrasa, closed type.

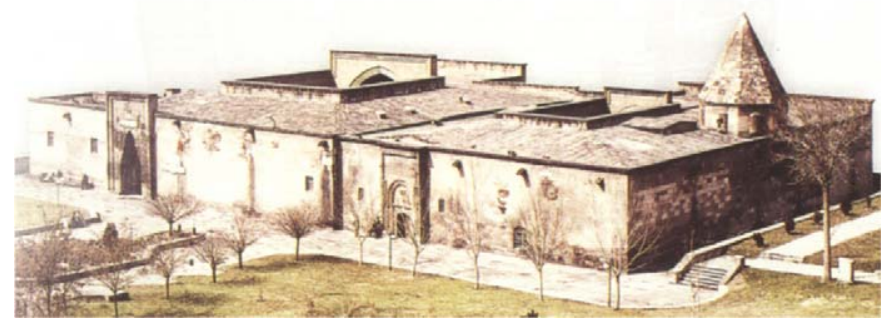

Fig. 3. Cut stone walls of Kayseri Çifte Madrasa (Gabriel A. Monuments Turcs d'Anatolie, vol. 1. Paris:E. de Boccard;1931).

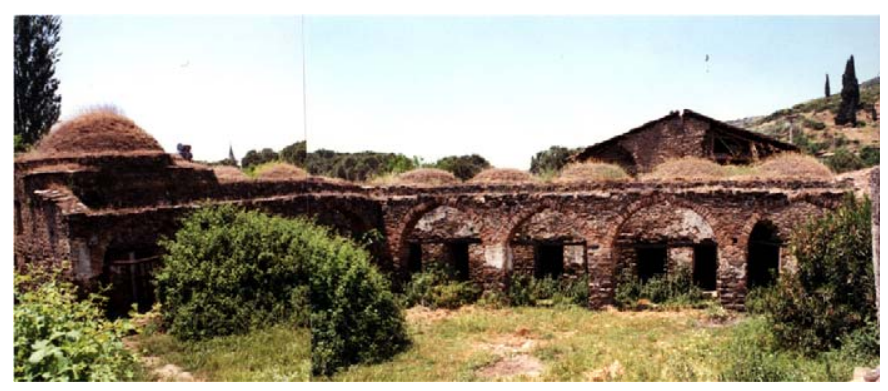

Fig. 4. Local construction technique composed of rubble stone, brick and mortar in random bond of Birgi Derviş Ağa Madrasa.

from cut stone both on the outer and inner surfaces (Fig. 3). The intermediate parts were filled up with rubble stone and mortar.

Madrasas were constructed continuously and increased in number during the Ottoman period developing as institutional buildings [5]. As for their planning, although at first the open and closed types were continued to be employed, later the vaulted iwans on the axes of the courtyard were removed and the madrasa rooms were designed in relation to the courtyard. Either in a single row, in two opposite rows, $\mathrm{L}$ formed or $\mathrm{U}$ formed. The spaces were covered with domes. The construction of madrasa buildings in small settlements in Western Anatolia, in addition to the ones built in larger cities like İstanbul, Edirne or Bursa, draw attention to the importance given to education. The ones built in such small settlements also reflect the general characteristics of Ottoman architecture. Although they were designed in moderate size, they reflect the local construction techniques and use of materials (Fig. 4).

In this context, this study focuses on three madrasas in Western Anatolia where examples of authentic architectural heritage from the Ottoman period, are conserved as values determining the cultural identity of the settlements. These are examined by taking into account the building materials defining their local characteristics and the climatic conditions of the area where they are situated. The climate is characterized by hot, nearly rainless summers (less than $10 \mathrm{~mm})$ and mild $\left(\sim 33^{\circ} \mathrm{C}\right.$ at noon), rainy winters $\left(\sim 100 \mathrm{~mm}, \sim 13^{\circ} \mathrm{C}\right.$ at noon), which is referred as a moderate climate. Adding to this moderate climate, 
which has no significant temperature changes between night, day and seasons, the buildings are not subjected to air pollution.

The madrasas chosen for this study from Western Anatolia show similar construction techniques. They are Hacı Sinan Madrasa in Bayındır, Nasuh Paşa Madrasa in Aydın and Derviş Ağa Madrasa in Birgi (Fig. 4) dating back to the 16th and the 17th centuries. In these buildings, the common local construction is rubble stone and brick masonry, which is not homogeneous. The stones and bricks are different in their dimensions. Irregular stone and brickwork suggest that the buildings may have been the work of local builders who continued the older tradition of the region.

Although stone and brick were used in a simple workmanship for the configuration of the building components, their survival in the centuries is worth noting. Therefore, this study investigates local experimentations in the Ottoman period madrasas from the point of the relationship between the properties of the materials used and the climatic conditions of the region and to evaluate their survival until today in spite of their being abandoned and neglected for a very long period.

\section{Present conditions of the studied madrasas}

The studied madrasas have survived up to the present preserving their original plan, mass and façade characteristics as well as their materials without structural and morphological interventions. The walls were constructed in random bond with stone and brick in different dimensions and mortar as a binding material. The walls and the piers, which constitute the arcades, were built of slate and brick; arches, domes and pendentives, which provide transition to the dome in the rooms, were built of brick and lime mortar as a binding material. The walls are covered with lime plaster while the exterior surfaces of the domes are covered with brick-lime plaster (horasan). Lime plasters were applied in two layers on the exterior and interior surfaces of the walls while horasan plaster was applied in one layer by itself on the superstructure to prevent the penetration of rainwater. These madrasas, which have lost their original functions, are unoccupied, neglected and are exposed to environmental effects.

Furthermore, as the result of the destruction of the neighborhood drainage system and damages on the superstructure, the problems of dampness and plant formations are observed. The material deterioration is dense on the sections of the walls up to approximately $1 \mathrm{~m}$ from the ground level.

\section{Properties and deterioration problems of the materials used in the buildings}

Besides general conditions of the buildings determined by visual observation, the physical, chemical, mineralogical and microstructural properties and deterioration problems of their original materials were investigated by laboratory studies. For this purpose, stone, brick, mortar and plaster samples were collected from relatively sound as well as from the deteriorated parts of the buildings.

In order to evaluate the deterioration of the building materials, basic physical properties, such as porosities and bulk densities were determined by standard test methods [9]. Soluble salt contents in the samples were detected by electrical conductivity method and anions in the salts were determined by spot tests $[10,11]$ on the collected stone, brick and mortar samples.

The binder/aggregate ratios and particle size distribution of the aggregates were determined after the dissolution of carbonated lime $\left(\mathrm{CaCO}_{3}\right)$ in dilute hydrochloric acid $(5 \%)$ in order to determine the raw material compositions of the mortars [12]. The pozzolanic activities of aggregates used in the mortars were determined by mixing them in a saturated calcium hydroxide solution and measuring the differences in electrical conductivity [13].

Mineralogical compositions were determined by using Philips X-Pert Pro X-ray diffractometer. Microstructure and chemical compositions were determined with a Philips XL 30S FEG scanning electron microscope (SEM) coupled with X-ray energy dispersive system (EDS).

The relationship between the climatic conditions and the deterioration problems of the building materials were examined based on data taken from the General Directorate of State Meteorological Affairs, Ankara. The essential meteorological parameters were taken as temperature, moisture, and wind speed.

The physical, mineralogical and chemical properties and deterioration problems of stone, brick, mortar and plaster used in the madrasas are examined separately as follows:

\subsection{Stones}

The stones used in the madrasas were identified as slate by mineralogical and petrographical analysis. The slate mainly consists of feldspar and quartz minerals (Fig. 5). Chemical composition analyses carried out by SEM/EDS indicated that these minerals were mainly composed of silicon $(\mathrm{Si})$, aluminum $(\mathrm{Al})$ and iron $(\mathrm{Fe})$ elements. Slate is

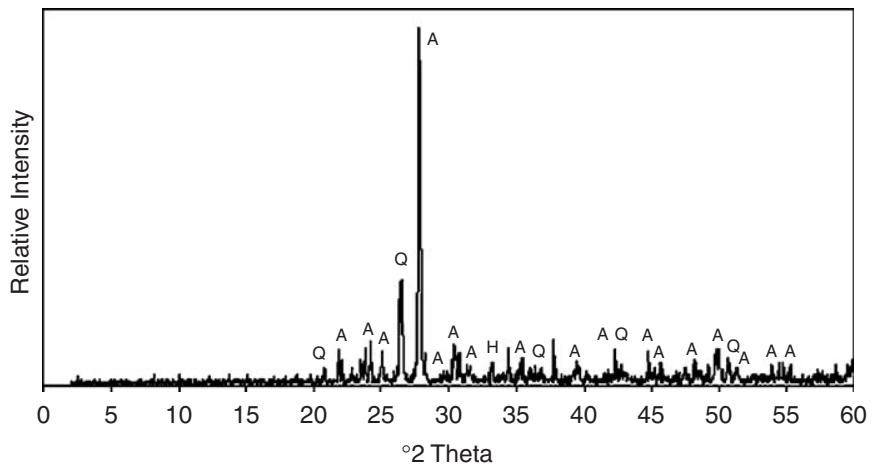

Fig. 5. X-ray diffraction (XRD) pattern of stones (A: albite, Q: quartz, H: hematite). 


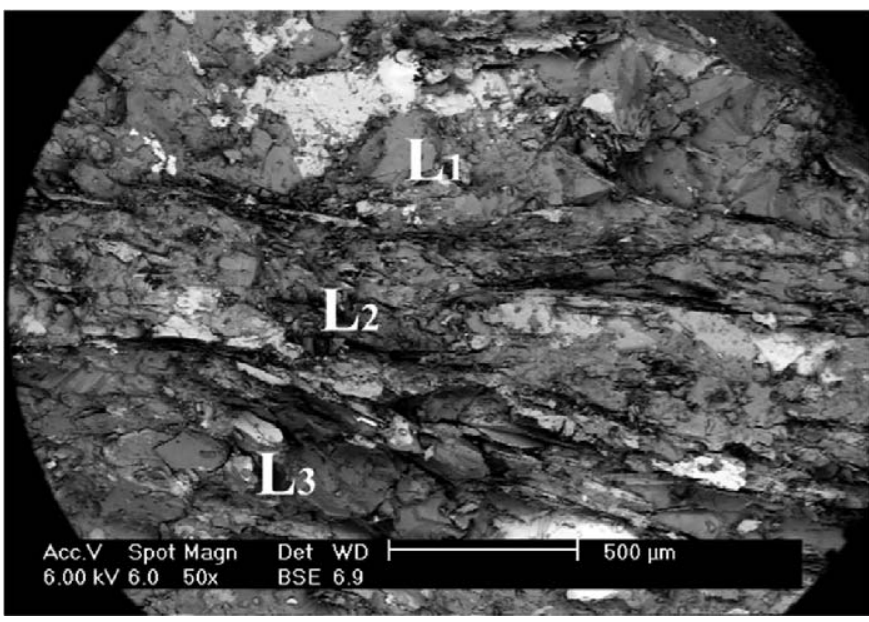

Fig. 6. Back-scattered electron (BSE) images of the detachments as in the form of layers in stones $\left(\mathrm{L}_{1}, \mathrm{~L}_{2}, \mathrm{~L}_{3}\right.$ layers).

formed from argillaceous sediments or volcanic ash by metamorphism under pressure [14]. In the result of this formation, it has a regular crystalline fabric of overlapping layers.

The average densities and porosities of relatively sound stones were $2.5 \mathrm{~g} / \mathrm{cm}^{3}$ and $2 \%$, respectively. Densities of stones on the relatively deteriorated parts up to approximately $1 \mathrm{~m}$ from the ground were lesser (approximately $2.3 \mathrm{~g} / \mathrm{cm}^{3}$ ) while their porosities were higher (approximately $4 \%$ ).

Soluble salt contents of the stones on relatively undeteriorated parts were around $0.2 \%$ while on the relatively deteriorated parts up to approximately $1 \mathrm{~m}$ from the ground, this ratio reached up to $0.6 \%$. Mainly nitrate and chloride ions were detected from the qualitative analyses. Since the highest amounts of these ions were found in the soil, it can be suggested that rising damp is the source of the salts. The stones, which contain the highest amounts of salts, were detached as in the form of layers. Besides salts, clay minerals were determined in the zones of detachment of the layers (Fig. 6). Both salts and clays caused deterioration of stone in the form of detaching layers that form the fabric of the stone during the cycles of wetting and drying.

\subsection{Bricks}

It was determined that the bricks were mainly composed of quartz, feldspar, hematite and muscovite by XRD analyses (Fig. 7). Considering these results, it can be said that calcite-poor clay was used in the production of the bricks. In the chemical composition, analyses carried out by SEM/EDS indicated silicon ( $\mathrm{Si}$ ), aluminum (Al) and iron $(\mathrm{Fe})$. Observation of hematite in the XRD analyses showed that the firing temperatures of bricks were $850{ }^{\circ} \mathrm{C}$ or higher [15].

Density and porosity values of bricks were around $1.8 \mathrm{~g} / \mathrm{cm}^{3}$ and $35 \%$, by volume, respectively. On relatively

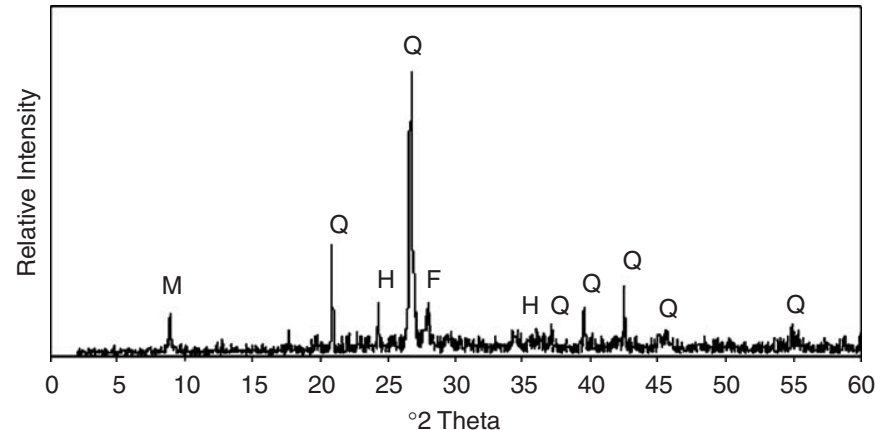

Fig. 7. XRD pattern of bricks (Q: quartz, H: hematite, F: feldspar, M: muscovite).

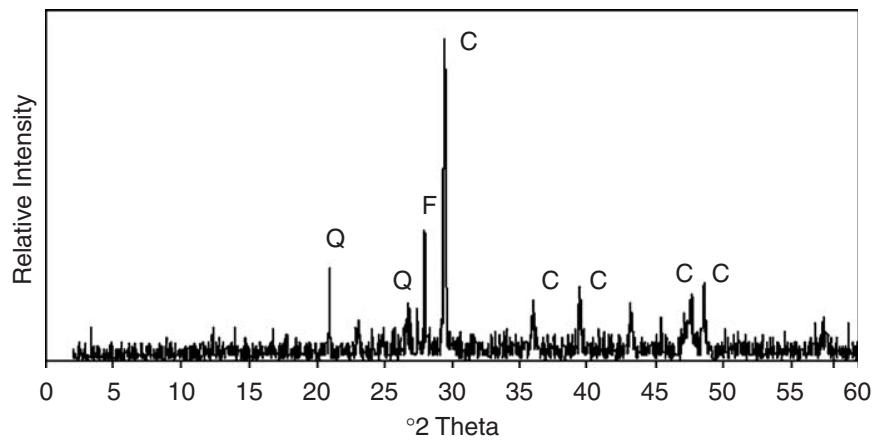

Fig. 8. XRD pattern of mortars (C: calcite, Q: quartz, F: feldspar).

deteriorated parts, density values decrease while porosity values increase. Soluble salt contents on relatively more deteriorated parts reached up to $5 \%$. Mainly nitrate and chloride ions were detected from the qualitative analyses as in the stones. These results indicate that the rising damp and the salts carried from the earth were effective factors on the deterioration $[14,16]$.

\subsection{Mortars}

In the buildings, lime mortars were used as binding material in the joints of brick and stone bonds. XRD analyses of mortars showed that they were mainly composed of calcite, quartz and feldspar minerals (Fig. 8). Calcite is derived from carbonated lime; quartz and feldspar from aggregates. Chemical compositions of white lumps in the mortars, determined by SEM/EDS, indicate that they were composed of high ratios of calcium oxide, around $95 \%$, and low ratios of magnesium oxide, around $2 \%$. These values showed that lime used in the preparation of the mortars contained low amounts of magnesium oxide (fat-lime).

Lime/aggregate ratios in stone masonry mortars were around 1:3 by weight, and in brick masonry mortars were 1:2 by weight. Aggregates used in the mortars were mainly composed of fine aggregates. In all of the samples, the aggregates with particle sizes between 53 and $1180 \mu \mathrm{m}$ composed the largest fraction of the total aggregates and this ranged between $85 \%$ and $95 \%$ within the total aggregates. 


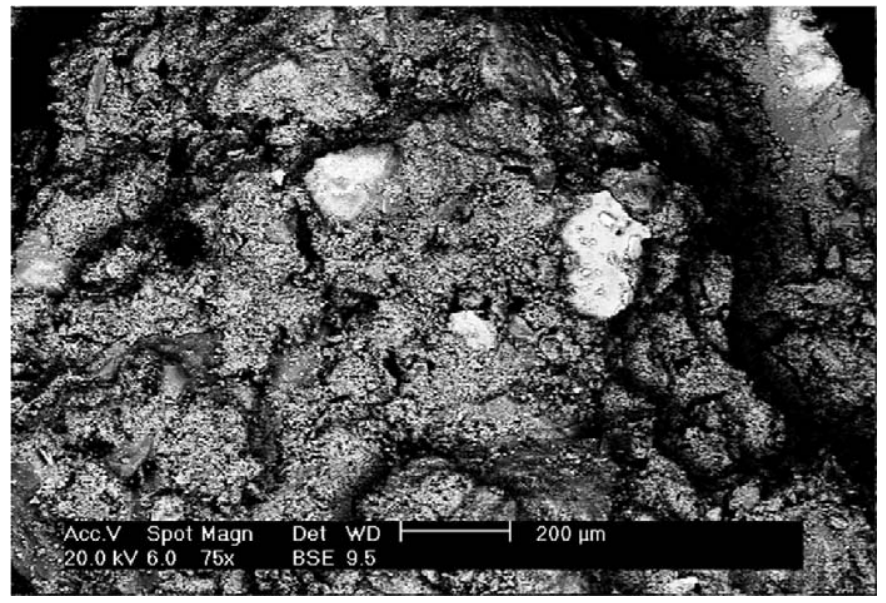

Fig. 9. BSE image of detachments between lime matrix and aggregates and fissures in the relatively deteriorated mortars.

Density and porosity values of stone masonry mortars, which contained lower percent of lime, were around $1.75 \mathrm{~g} /$ $\mathrm{cm}^{3}$ and $30 \%$, by volume, respectively. The average density and porosity values of brick masonry mortars were $1.60 \mathrm{~g} /$ $\mathrm{cm}^{3}$ and $40 \%$, by volume, respectively.

Pozzolanic activity measurements of aggregates used in the mortars revealed that they are pozzolanic since pozzolanic activity values are more than $1.2 \mathrm{mS} / \mathrm{cm}$, which is accepted as good pozzolan [13]. Considering the pozzolanicity of the aggregates, it can be claimed that the mortars were hydraulic.

Interface between lime matrix and aggregates is free from pores and cracks in the mortars on the relatively sound parts. This observation may indicate a well-mixing process of the lime with the aggregates. In the mortar samples on the relatively deteriorated parts up to approximately $1 \mathrm{~m}$ from the ground, the observation of detachments at the interface between lime matrix and aggregates and fissures in the matrix could be explained by the crystallization of soluble salts carried from the earth by the rising damp (Fig. 9).

\subsection{Plasters}

Lime plasters used on the outer and inner surfaces of the walls comprised of two layers; the top layer, which is $0.5 \mathrm{~cm}$ in thickness while the under-layer varied between 1.3 and $2.5 \mathrm{~cm}$ in thickness. Horasan plaster used on the exterior surfaces of the domes as the superstructure is approximately $3 \mathrm{~cm}$ in thickness.

Raw material properties and chemical compositions of plasters were examined separately in the lime and horasan plasters.

\subsubsection{Lime plasters}

It was determined that the two-layered plasters used on the walls were well bounded to each other. Since the surface of the under-layer plaster was rough and treated specially to provide a good adhesion in between the two

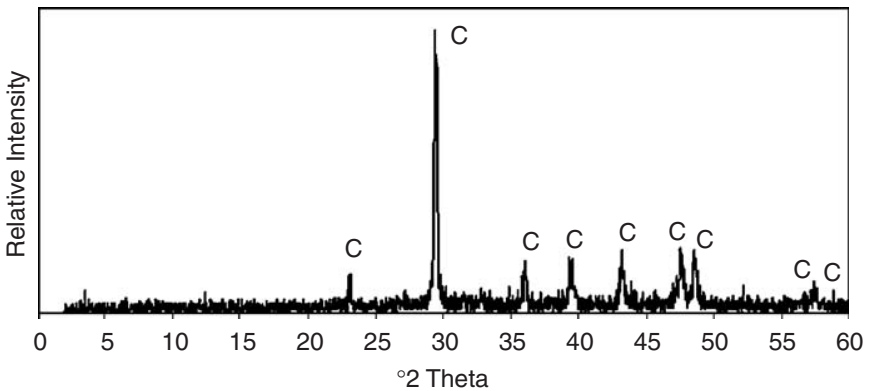

Fig. 10. XRD pattern of the top-layer plasters (C: calcite).

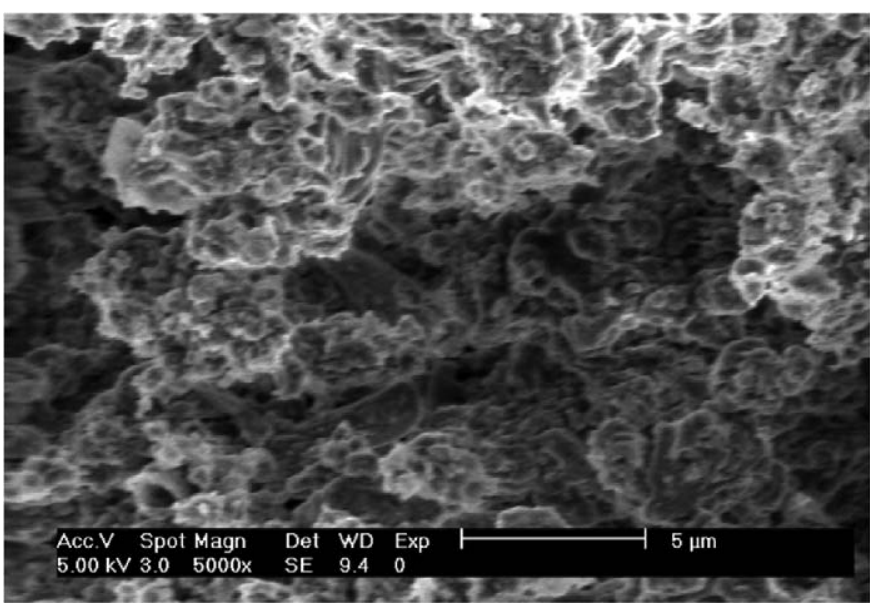

Fig. 11. Secondary electron (SE) image of micritic calcite crystals in the top-layer plasters.

layers it can be suggested that the lime plasters were originally applied as two-layered.

Top-layer plasters were composed of $97 \%$ binder and lower amounts of fine aggregates (3\%). Mainly calcite peaks were observed in their XRD patterns (Fig. 10). Calcite crystals were in micritic structure and contained 95\% $\mathrm{CaO}$ (Figs. 11 and 12). These results indicated that pure lime was used in the production of the plasters.

Under-layer plasters were composed of $60 \%$ aggregates and $40 \%$ by weight binder. Fine aggregates were used in the manufacturing of under-layer plasters as in the mortars.

Besides calcite mineral, quartz and feldspar peaks coming from aggregates were observed in the XRD patterns of the under-layer plasters (Fig. 13). As observed in the top-layer plasters, calcite crystals were in micritic structure.

Interface between aggregates and binder, pores and cracks were observed in the plasters on the relatively deteriorated sections (Fig. 14). It can be asserted that these formations, which caused to the disintegration of plasters, originated from the rising damp and the salts that were carried from the earth as in the mortars.

\subsubsection{Horasan plasters}

Horasan plasters were composed of lime as binder and brick fragments as aggregate. The average weight percentages of binder and brick fragments were around $60 \%$ and 


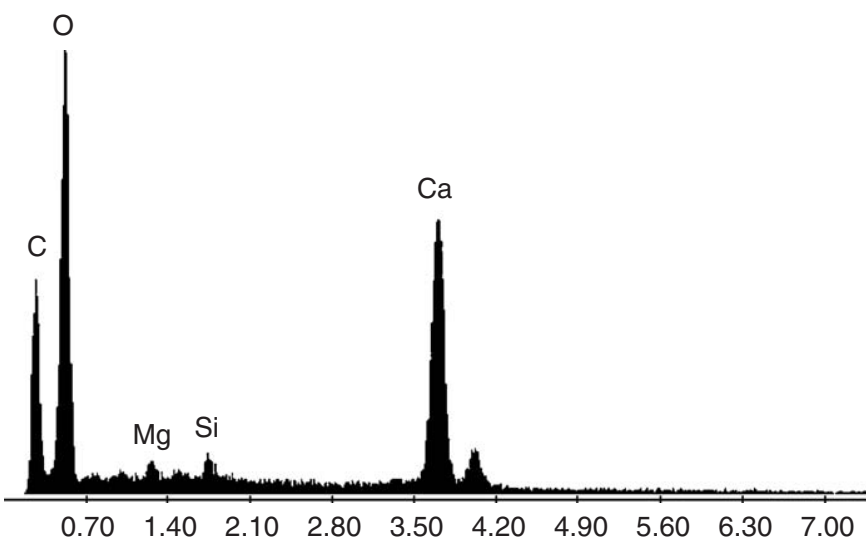

Fig. 12. Energy-dispersive spectroscopy (EDS) analysis of micritic calcite crystals in the top-layer plasters.

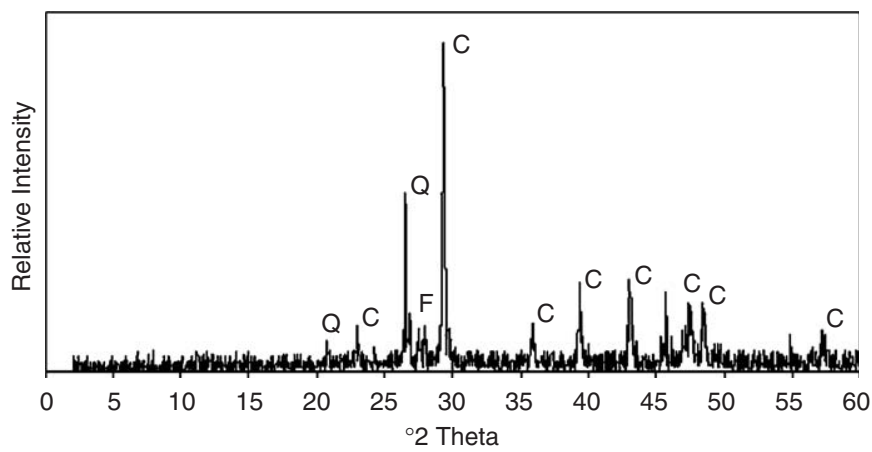

Fig. 13. XRD pattern of the under-layer plasters (C: calcite, Q: quartz, F: feldspar).

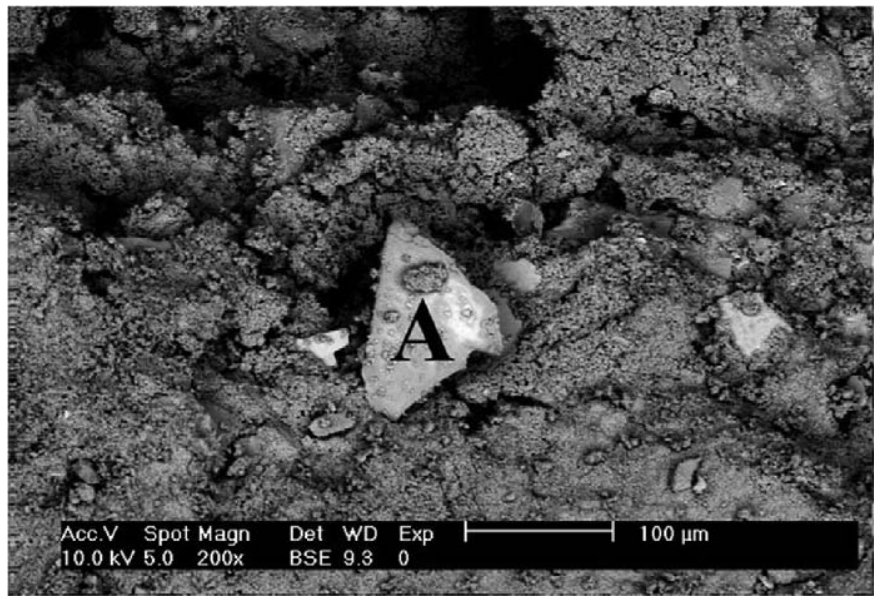

Fig. 14. BSE image of detachments between aggregates and plaster matrix in the relatively deteriorated plasters (A: aggregate).

$40 \%$, respectively. The coarse brick particles over $1000 \mu \mathrm{m}$ had the highest percentage around $18 \%$ while the ratio of fine aggregates below $53 \mu \mathrm{m}$ decreased to $1 \%$.

Calcite and quartz peaks were determined by XRD analyses of horasan plasters (Fig. 15). Calcite originated from the carbonated lime and quartz from the brick aggregates. Besides mainly calcium, low percentages of

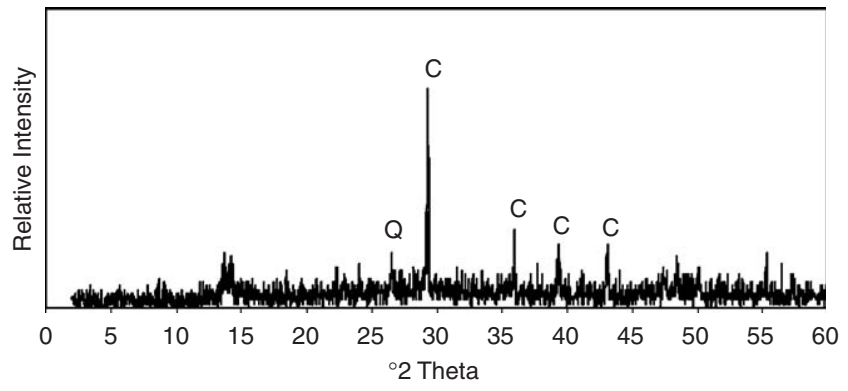

Fig. 15. XRD pattern of horasan plaster (C: calcite, Q: quartz).

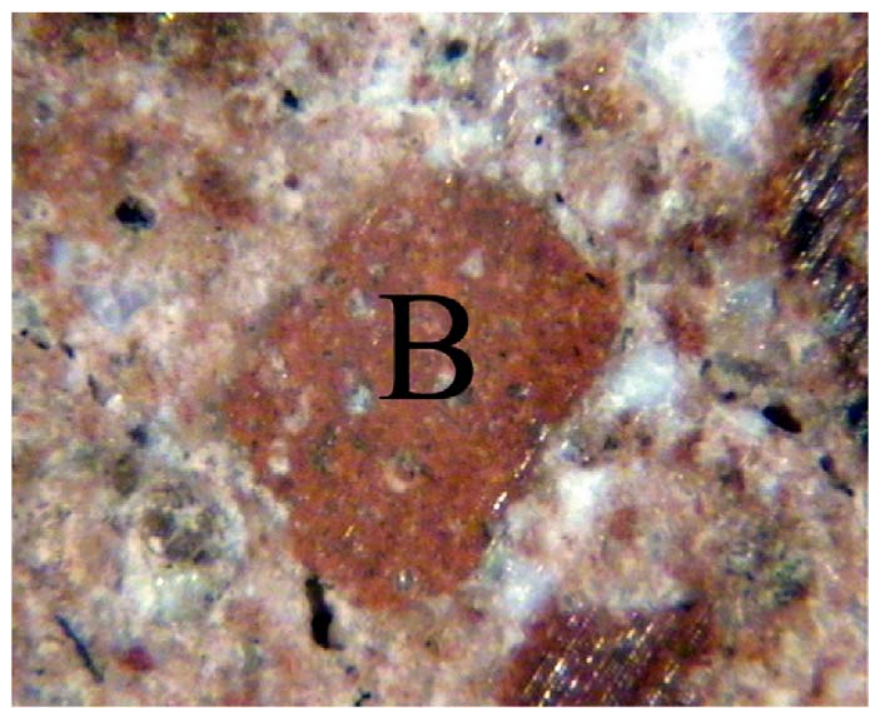

Fig. 16. Stereo microscope image of the brick aggregate (B) in the horasan plaster matrix.

silicon and aluminum, which were possibly derived from brick aggregates, were determined in SEM/EDS analyses of the lime matrix.

Brick fragments were adhered well with the lime and the interface between the lime matrix and brick fragments was free from cracks (Fig. 16). In these plasters, calcium silicate hydrate and calcium aluminate hydrate formations were also detected in the results of the reaction between lime and brick fragments [17]. These products acquire hydraulic properties to horasan plasters (Fig. 17). Horasan plasters were applied as an isolation material on the superstructures of numerous historical buildings due to their hydraulic properties.

\section{The climate of Western Anatolia}

One of the important factors effective on the decay of historical building materials is the climatic conditions where the buildings are located. Climatic factors such as high humidity, high rainfall, low temperature in addition to seasonal changes and drastic fluctuations in temperatures of day and night accelerate the deterioration of building materials. 


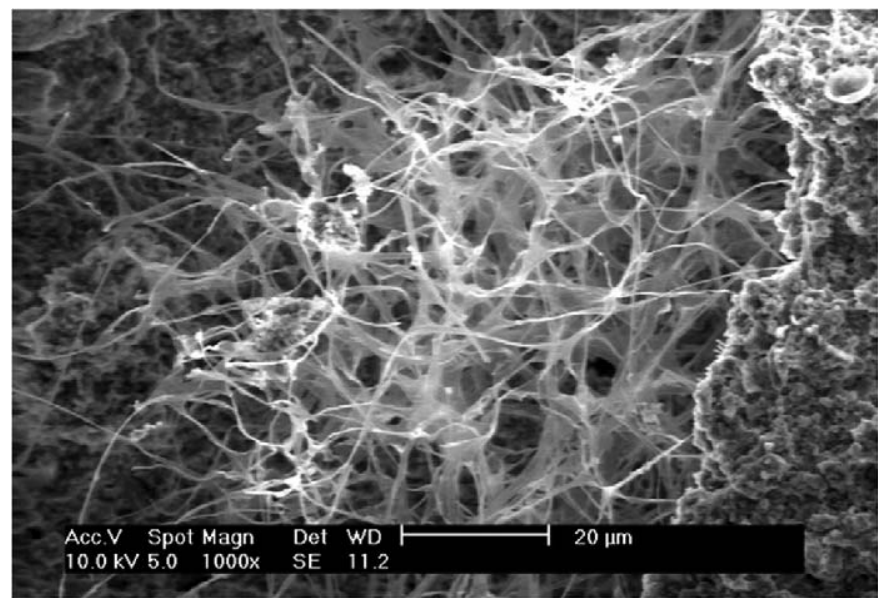

Fig. 17. SE image of calcium-silicate-hydrate (C-S-H) formations in the horasan plaster.

In the region where the studied buildings exist, the average temperature, dew point temperature and humidity values recorded at 7:00, 14:00, and 21:00 using meteorological data of the last decade were evaluated. Relative humidity is high and temperatures are low during the winter months December, January and February. While relative humidity decreases and temperatures increase during the summer months June, July and August. As for the spring months and fall months, these values are between the temperature and relative humidity values observed during the winter and summer months (Fig. 18).

As shown in Fig. 18, temperatures are below $5^{\circ} \mathrm{C}$ and relative humidity is over $80 \%$ at 7:00 during the winter months. Dew point temperatures are close to ambient temperatures at that time. Condensation of water vapor occurs when the temperature of the air is lowered to its dew point. When the surface temperature of building material is lower than the dew point temperature, the moisture in the air condenses on the building material [18]. These results indicate that the possibility of condensation of water on the building materials is high. At 14:00, temperature rises above $10{ }^{\circ} \mathrm{C}$, differences between dew point temperatures and air temperatures increase and relative humidity decreases. These results show that there is a low possibility of condensation of water in the afternoon during winter months. At 21:00, temperatures drop again below $10^{\circ} \mathrm{C}$, while the dew point temperatures are close to the ambient temperature and relative humidity increases. These results indicate that the temperatures decrease, while dew point temperatures are close to the average temperatures and the humidity increases between 21:00 and 7:00 during winter months. It is understood from these results that there is a high risk of condensation of water on the building materials throughout the night during the winter months.

During the months March, April, October and November of spring and autumn, at 7:00, temperatures range between 5 and $12{ }^{\circ} \mathrm{C}$ and relative humidity is higher than
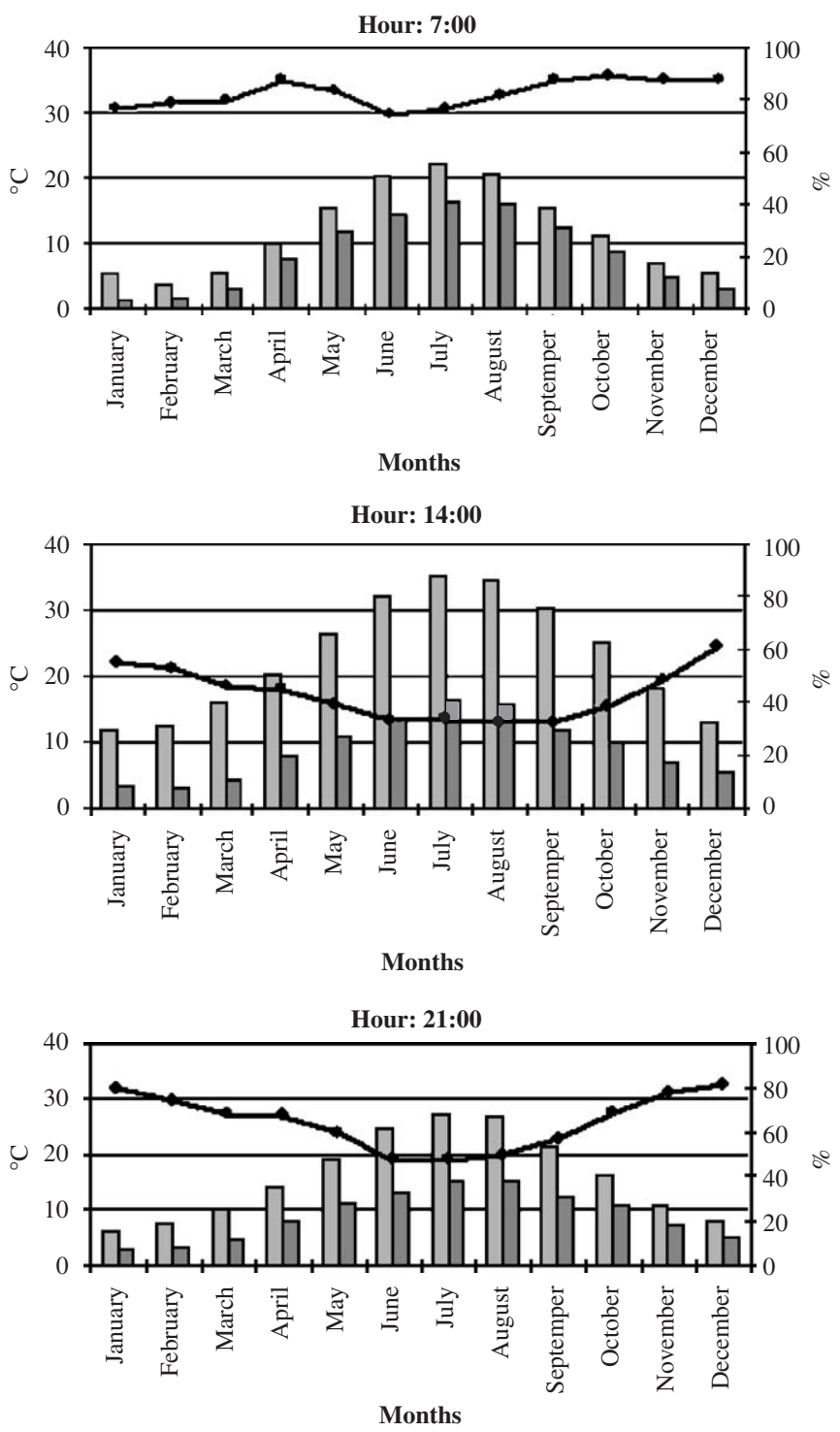

$\square$ Ambient Temp. $\square$ Dew Point Temp $\longrightarrow$ Relative Humidity

Fig. 18. Average values of the average monthly values of ambient temperature, relative humidity and dew-point temperature between the years 1994 and 2004; hour: 7:00, 14:00, 21:00 (General Directorate of State Meteorological Affairs, Ankara).

the winter months, ranging between $85 \%$ and $90 \%$. At that time dew-point temperature values are close to the ambient temperatures. These results show that there is a possibility of condensation of water in the building materials during the mentioned months. At 14:00, the temperature rises above $15^{\circ} \mathrm{C}$, differences between dew-point temperatures and air temperatures increase and relative humidity decreases. These results point out that there is no possibility of condensation of water; however, the possibility of evaporation increases due to rising temperatures. At 21:00, temperatures drop below $15^{\circ} \mathrm{C}$, while dew-point temperatures are close to air temperature and relative humidity increases. These results indicate that there is a 


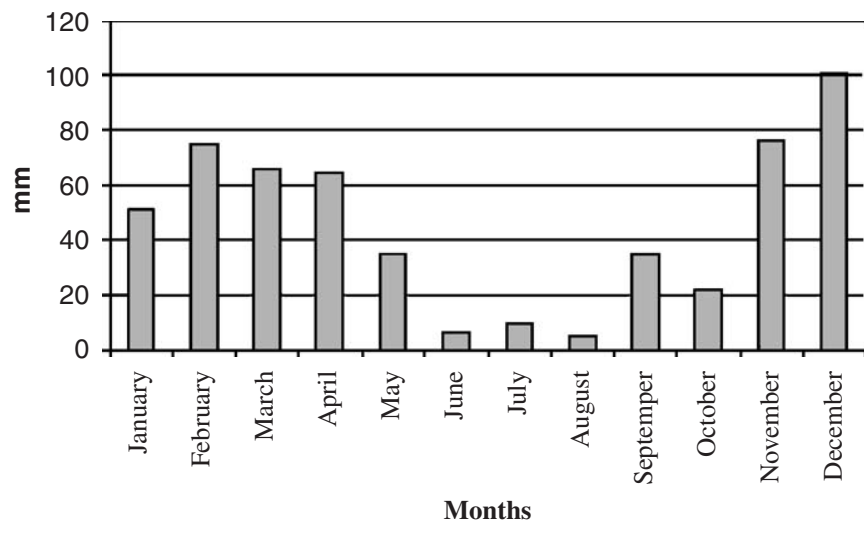

Fig. 19. Average values of the average monthly values of rainfall between the years 1994 and 2004 (General Directorate of State Meteorological Affairs, Ankara).

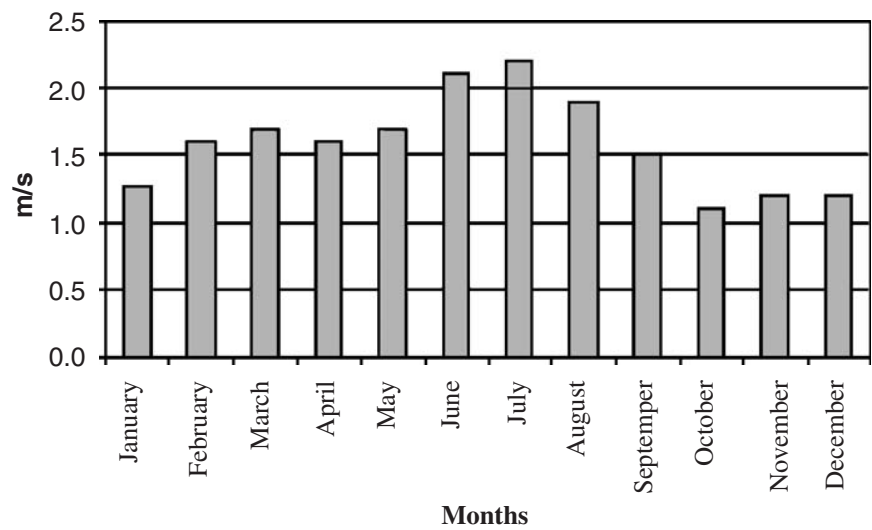

Fig. 20. Average values of the average monthly values of wind speed between the years 1994 and 2004 (General Directorate of State Meteorological Affairs, Ankara).

risk of condensation of humidity between 21:00 and 7:00 during these months.

During summer months at 7:00, temperatures are around $20{ }^{\circ} \mathrm{C}$, relative humidity is around $80 \%$ and dewpoint temperature values are lower than the ambient temperature. These show that there is low possibility of condensation of water in the building materials during summer months. At 14:00, temperature rises above $30^{\circ} \mathrm{C}$, differences between dew-point temperatures and air temperatures increase and relative humidity decreases. These results point out that there is no possibility of condensation of water during the afternoon hours. At 21:00, temperatures drop below $30^{\circ} \mathrm{C}$, while relative humidity increases. These results indicate that there is no risk of condensation of humidity between 21:00 and 7:00 during these months.

The months May and September of spring and autumn, have temperature and relative humidity values between spring and summer months. When the temperatures of all months are examined, it can be observed that the temperatures do not drop to zero or below. This indicates that water does not freeze in the building materials.

During the summer months, the average rainfall is low while wind speed is high (Figs. 19 and 20). This situation reduces the humidity in the building creating more dry air. During spring, autumn and winter months, the average rainfall is high while wind speed is low, and this increases the dampness problems in the buildings due to the increase in the humidity in the air.

\section{Conclusions}

The survival of the studied madrasas until today may be explained with climatic conditions of Western Anatolia, construction techniques and the properties of the building materials used and further there were no extensive human destruction and/or natural disasters. In spite of a large number of drying-wetting cycles, which occur throughout the entire year, building materials such as slate, brick, lime mortar and horasan plaster are durable to the moderate climatic conditions. In addition, freeze-thaw cycles, which accelerate the deterioration of building materials, do not occur in these climatic conditions.

The studied Western Anatolian madrasas were constructed out of rubble stone and brick in masonry system with local workmanship of local builders who continued the old construction traditions of the region. Slate, which is a volcanic stone, is used in the construction of the buildings. Bricks used in the buildings were manufactured by using local clay sources that contain low calcium and firing over $850^{\circ} \mathrm{C}$. Production technologies of mortars are similar in the studied madrasas. Mortars used in three madrasas were produced with pure lime and pozzolanic aggregates. These mortars are hardened under water (hydraulic) and they are more durable than ordinary lime mortars. Plasters used on the walls have similar properties. Thicknesses of plasters and production technologies are also similar. Hydraulic plasters manufactured by using pozzolanic brick aggregates were used on the superstructures to prevent penetration of the rainwater into the buildings. The source of the deterioration observed on the building materials is the rising damp carrying soluble salts from the earth. Rising damp is not generated by ground water but by the destruction of the neighborhood drainage system. This indicated that the deteriorations observed on the building materials are not caused by the climatic conditions of the region.

The madrasa buildings located in the steppe climatic conditions, which is characterized by long and very cold winters, in Central and Eastern Anatolia, were covered with cut stone on their exterior surfaces to prevent their intermediate parts filled with rubble stone and mortar from harsh climatic conditions such as a large number of freezethaw cycles.

Thus, in conclusion, it is asserted that construction techniques and building materials appropriate to the 
climate may have been intentionally chosen for the survival of historical buildings over the centuries.

\section{Acknowledgments}

This research was developed within the research project Investigation of Methodology for the Classification of Deterioration Types and Problems in Historic Building Materials IÇTAG-I304 supported by the research grants of TÜBITAK. The authors thank the researchers of the Centre for Materials Research at the İzmir Institute of Technology for XRD and SEM-EDS analyses.

\section{References}

[1] Oktay D. Design with the climate in housing environments: an analysis in Northern Cyprus. Building and Environment 2002;37(10):1003-12.

[2] Ozay N. A comparative study of climatically responsive house design at various periods of Northern Cyprus architecture. Building and Environment 2005;40(6):841-52.

[3] Yetkin SK. İslam ülkelerinde sanat. İstanbul: Cem Yayınevi; 1974.

[4] Cezar M. Anadolu öncesi Türklerde șehir ve mimarlık. İstanbul: Türkiye İș Bankası Kültür Yayınları; 1977.

[5] Ahunbay Z. Medreseler. In: Dünden bugüne İstanbul ansiklopedisi, vol. 5. İstanbul: Türkiye Ekonomik ve Toplumsal Tarih Vakfi; 1994. p. $320-6$.

[6] Creswell KAC. The Muslim architecture of Egypt, vol. 2. Oxford: Clarendon Press; 1959.

[7] Kuran A. Anadolu medreseleri. Ankara: ODTÜ Yayını; 1969.
[8] Sayılı A. Higher education in Medieval Islam. Ankara Üniversitesi Yıllığ 1948;2:55.

[9] RILEM Commission 25 PEM. Tests defining the structure. Materiaux and Construction 1980;13(75):177-81.

[10] Arnold A. Determination of saline minerals from monuments. GP News Letter 1983;4:4-15.

[11] Black CA, editor. Methods of soil analysis, vol. 2. Madison, Wisconsin: American Society of Agronomy; 1965.

[12] Middendorf B, Knöfel D. Use of old and modern analytical methods for the determination of ancient mortars in Northern Germany. In: Proceedings of the third expert meeting, Hamburg; NATO - CCMS pilot study on conservation of historic brick structures, Berlin, Germany, 1990, p. 75-92.

[13] Luxan MP, Madruga F, Saavedra J. Rapid evaluation of pozzolanic activity of natural products by conductivity measurement. Cement and Concrete Research 1989;19(1):63-8.

[14] Schaffer RJ. The weathering of natural building stone. Garston: Building Research Station; 1972.

[15] Mitchell RS, Hart SC. Heated mineral mixtures related to ancient ceramic pastes: X-ray diffraction study. In: Allen RO, editor. Archaeological chemistry IV. Washington, DC: American Chemical Society; 1989. p. 145-55.

[16] Arnold A. Nature of reactions of saline minerals in walls. In: Ross MR, editor. Conservation of stone II, preprints of the international symposium. Bologna: Centro per la Conservacione delle Sculpture all Aperto; 1981. p. 13-23.

[17] Wang H, Gillot JE. Mechanism of alkali-silica reaction and the significance of calcium hydroxide. Cement and Concrete Research 1991;21(4):647-54.

[18] Oxley TA, Gobert EG. The professionals and home owners guide to dampness in buildings: diagnosis treatment instruments. London: Butterworths; 1985. 